\title{
EFFICIENCY OF USE OF BORROWED CAPITAL IN LITHUANIAN AGRICULTURAL COMPANIES
}

\author{
Lina Martirosianiene ${ }^{1}$ \\ ${ }^{1}$ Aleksandras Stulginskis University, Faculty of Economics and Management, Department of Economics, Accounting \\ and Finance, Lithuania
}

\begin{abstract}
Agriculture is an economy sector demanding big material resources for which modernization and further development investments are crucial. It provides additional competitive advantage and powerful tool for growth for the organizations and influences company financial status, business continuity and development. It is important to correctly choose such capital structure of the company which would minimize capital cost and increase value of the company. Borrowed capital helps to earn additional funds, i.e. undertaken financial risk can have positive effects on Return on Equity but investments are not always successful or become efficient. This article analyzes financial stability ratios of Lithuanian agricultural companies and evaluates the efficiency of use of borrowed capital. In order to evaluate the efficiency of use of borrowed capital the following relative financial indicators are used: Debt to Equity Ratio; Net Debt to EBITDA Ratio, Interest Bearing Loans to Debt Ratio, Return on Equity Ratio, and Financial Leverage Effect, which combines the risk of financial leverage and interest coverage with tax tariff.
\end{abstract}

Keywords: borrowed capital, return on equity, efficiency, financial leverage effect, debt. ***

\section{INTRODUCTION}

Agriculture is important from the economic, social, ethnocultural and environmental perspectives. It is an economy sector demanding big material resources for which modernization and further development investments are crucial. Nevertheless, as Sedlacek[19] states, agriculture business activities are especially influenced by many force majeure circumstances including unforeseen weather changes, climate warming, surplus or shortage of humidity. It is more difficult for agricultural subjects to transform their activities comparing to subjects in other economy sectors. This economy sector is especially influenced by biological factors, season ability of activities, changes of market demands, etc.

Therefore external funding sources are crucial for agricultural subjects willing to develop their businesses, modernize the production, increase working capital and make investment decisions. The benefits of borrowed capital are confirmed in both theory and practice, emphasizing that borrowed capital is the most convenient funding form which does not change the shares of equity shareholders in the company and helps to attract necessary funding. However, it is necessary to mention, when company increases the proportion of debt or substitutes debt for equity, equity shareholders feel that they are exposed to a higher degree of financial risk [13]. Therefore before making the decision to fund activities using external funding sources it is important to ensure that Return on Equity, which can be expressed by both net profit or net cash flow measurements, will increase sufficiently.

Capital structure is one of the key aspects for a successful operation of any company. Theoretically, there are several approaches that explain this notion, including: Milller-
Modigliani theory (1963), trade-off theory, pecking order theory - Myers (1984), Myers \&Majluf (1984), agency theory - Jensen \&Meckling (1976), the market timing theory, etc. [20]. In essence, capital structure is targeting long-term funding sources used by companies to finance their development and to increase their market value.

Goal of the research - to explore debt level and efficiency of use of borrowed capital in Lithuanian agricultural companies after analyzing the fundamentals of capital structure in company activities.

In order to reach the goal, the following tasks will be conducted: (1) analysis of the concepts of borrowed capital and capital structure; (2) identification of main methods for analysis of efficiency of use of borrowed capital; (3) analysis of debt level and efficiency of use of borrowed capital in Lithuanian agricultural companies.

The research was conducted by analyzing previous research works, practical experience and by logically generating conclusions and recommendations. Scientific literature was theoretically analyzed by employing the methods of analysis and synthesis. Research findings are presented by monographic and comparative ratio analysis methods.

\section{LITERATURE REVIEW}

For most agricultural enterprises the own capital is the main part and the base of the all financial capital, but now it is difficult to rely on high-quality production and trading activities without borrowing. The use of borrowed resources makes it possible to increase the profitability of own capital, but negatively effects the financial stability of the company [8]. 
The stability of every company is determined while analyzing its capital structure, i.e. Debt to Equity Ratio, which shows what part of capital company funds with debts and which - by equity. General debt level in the company is adversely proportional to stability of the company. As Ross et al.[18] state, it is very important to correctly choose such capital structure of the company, which would minimize capital cost and increase the value of the company. In the opinion of Pettit [16], optimal funding policy, including capital structure, cash flows and company liquidity is not only a choice of the best combination of mentioned objects but also its correct adaptation to company strategy and market expectations. However, Vătavu[21] contradicts traditional theory of capital structure, which strongly believes that the optimal mix of capital ensures a low weighted average cost of capital that maximizes the market value per share; he states, that the leverage and equity ratios are not sufficient in determining performance, because there are multiple factors interfering in these relationships.

While funding a big part of assets with debts one can expect greater efficiency of company activities and, at the same time, greater part of profit being attributed to equity. However, big debts increase insolvency risk in the company. As Wu et al. [22] state, how agricultural businesses choose their debt level has important implications for farm performance, farm financial risk and business survival rates. They find that firm profitability, growth potential, and land tenure have significant effects on farm capital structure choice at almost all leverage levels, while risk attitude proxies, fixed asset ratio, farm size, and legal form of ownership only exhibit influences over certain leverage ranges. Akintoye[1] confirmed the role of business risk, taxes, managerial behavior or financial flexibility in the analysis of firm performance. He explained that since the capital structure is based on the trade-off between risk and expected return, these are crucial factors in determining a target capital mix.

Companies with a track record of achieving a rate of return on assets above the rate of interest on debt should have greater access to leverage and be more willing to use debt, because such a strategy will positively leverage the rate of return on equity. At the same time, the cost of capital is assumed to be less for high-profit companies. In contrast, if companies have gone through periods of low profitability, it is possible they would have greater need for debt funds. Regardless of the scenario, it seems possible that profitability would impact debt use [4].

The results of empirical research of Khrawish and Khraiwesh[14] show that profitable companies mostly use smaller debt ratio comparing to less profitable companies. Collins et al.[6] also confirmed by their scientific research that profitability is negatively related with debt ratio of the company. Rajan and Zingales[17] found that leverage increased with asset structure and size, but decreased with growth and profitability.
Therefore it is very important to analyze the dynamic of debt ratio and evaluate main debt indicators. Al-Shubiri[3] notices that borrowed capital also has some negative effects, including (1) increased bankruptcy risk due to increased liabilities, (2) reduced possibilities of attracting potential investments, and (3) increased burden of payable interests. In the opinion of Bratka and Praulins[4], the relationship between the proportion of assets financed with debt and return on equity is unclear, because interest expense is added to net company income in the calculation of return, the effect of debt use should, in theory, be zero. However, managers would be expected to use debt funds to acquire resources they consider to be highly profitable and which would enable them to increase return on equity.

In conclusion it can be stated that most authors relate financial risk with financial leverage. Companies which finance their activities with borrowed funds might face interest deviations and cash flows disorders, meanwhile those companies who use less borrowed funds might face the depreciation of invested capital. Borrowed funds help to earn additional funds, but investments are not always successful and become efficient. From the other side, if borrowed capital is not used efficiently a risk of business subject bankruptcy arises, which cause both economic and social problems. In order to avoid these problems it is crucial to correctly evaluate expected economic efficiency of borrowed capital.

\section{RESEARCH METHODS}

It is obvious that both financial leverage and debt indicators influence the activities of the company. If company correctly invests borrowed funds the efficiency increases. In scientific literature the following relative financial indicators are used to evaluate the efficiency of borrowed capital: Debt to Equity Ratio; Debt to Asset Ratio (ROA) and Return on Equity Ratio (ROE).

Damaret al.[7] state, that high Debt to Equity Ratio illustrates that a company is operating with debt as its capital. When used correctly, a company's debt can be generated to profits compared to operating by using its own equity. This shows that there is positive correlation between Debt to Equity Ratio towards profitability. This indicator can also be calculated as Interest Bearing Loans to Equity Ratio while determining the financial leverage effect.

Debt to Asset Ratio shows what part of company's assets is funded by debts, however, in the opinion of Ellinger et al. [9], the Debt to Asset Ratio may not be an effective indicator of the level of debt that can be serviced by a company borrower or an adequate metric of financial stress in the agricultural sector, the debt - servicing to income ratio is an alternative metric. The level of debt for commercial loans is also typically driven by the ability to generate cash. Ellingeret al.[9] argued that the most common measure of leverage is Net Debt -debt less cash and equivalents divided by Earnings before Interest Taxes, Depreciation and Amortization (EBITDA). EBITDA is a commonly-used 
proxy for cash flow being generated by a business prior to debt service and income taxes.

In general, higher profit means higher return for the investors. According to Signaling Theory, which states that when a company sends a good signal to the market in the form of information, the market will be able to determine which companies has good performance [7]. Looking only at the basic formula for ROE it can be concluded that the increase in ROE requires either growth of Net Income or reduce the equity (i.e., increase the debt). According to the authors direct impact on ROE have operational decisions, financial decisions and tax effect: 1) Operational decisions are expressed by Return on invested capital before tax which is the ratio of pre-tax profit to invested capital; 2) Financial decisions result from two factors: financial cost effect that in case of high leverage reduces ROE, and financial structure effect that in such case increases ROE; 3) the tax effect expressed by the incidence of company tax [15].

In Neo-Classical models of purposeful capital structure formation the most important goal of the company is maximization of value of shareholders assets, where management of the company is solely directed towards the interests of shareholders [11]. Besides analyzed cost these models also emphasize the importance of risk of capital investment: financial and business risk. Financial risk expresses additional risk which is a consequence of capital structure of the company. It evaluates situations when in case the company is in a difficult economic situation, it pays smaller interests for invested equity comparing to the interests for borrowed capital for which constant payable interest amount is agreed. Due to these fixed payments for borrowed capital the deviations of net profit (after paying interests) amount is bigger than deviations of gross profit, and difference between these indicators increases with growing debt ratio.

In the opinion of Cibulskieneet al [5] financial risk influencing the capital structure might be calculated using the formula of Financial Leverage Effect:

$$
r_{E}=w_{a c c}+\left(r_{A}-r_{D}\right) \cdot \frac{D_{m}}{E_{m}}
$$

where: $r_{E}$-cost of equity; wacc $_{A}$ - weighted average cost of capital; $r_{A}-$ cost of total capital; $r_{D}-$ cost of borrowed capital; $D_{m}-$ market value of borrowed capital; $E_{m}-$ market value of equity.

Financial leverage effect states that increased debt ratio leads to proportional growth of equity profitability till the interest rate of borrowed capital becomes lower than the profitability of total capital [5].

Ilie and Olaru[12] notice that the tax system brings an advantage for the debt financing. Debt financing has an important advantage: interest is tax-deducible. Therefore a very important financial risk indicator is Financial Leverage Effect which combines interest coverage risk with tax tariff. While analyzing and evaluating the financial advantage of borrowed capital and determining its' impact on the efficiency of Latvian agricultural holdings Bratka and Praulins[4] used the following formula of Financial Leverage Effect:

$$
E_{f l}=(E B I T / \text { total assets }-j) \times(1-t) \times D / E(2)
$$

where: $D$ - outstanding interest bearing loans; $E$ - equity; $t-$ tax rate; $j$-interest rate.

Keeping in mind that financial risk is a consequence of capital structure of the company, in order to evaluate the impact of financial leverage, interest coverage and tax tariff to financial risk and profitability this research will use the formula below (3) [2]:

$$
F L E=(1-t) \times(r-i) \times D / E
$$

where: $r$ - profitability of total capital $(E B I T /(D+E)) ; i-$ interest rate.

It is obvious that Financial Leverage Effect is rather dangerous instrument because if only the interest rate becomes bigger than the profitability of total capital, the effect begins to act against the benefits of the company. In this case the bigger financial leverage effect, the bigger is the loss that shareholders or the company experience.

\section{DATA ANALYSIS AND FINDINGS}

With high business risk in agriculture sector, high Debt on Equity Ratio increases financial risk. It is necessary to emphasize that subsidies related to assets are attributed to equity and this can artificially increase the financial stability of the company.

Table 1 shows changes of borrowed capital levels and efficiency of its use in Lithuanian agricultural companies in 2010 - 2015.

Debt on Equity Ratio show that Lithuanian agricultural companies used less borrowed capital comparing to equity during all analyzed period. It can be concluded that a high percentage of agricultural companies have little or no debt, the aggregate measure provides little evidence of the proportion of companies with high levels of financial leverage and financial risk. Debt on Equity ratio shows that financial risk of the company decreases when weight of equity in the capital structure grows which increases the possibilities of the company to attract investors.

Conducted research have shown that in Lithuanian agricultural companies, grouping according to economic size, Debt to Equity ratio changes from 0,41 to 0,15 during the analyzed period. While analyzing the dynamics of accepted financial risk it can be stated that higher risk is determined in those agricultural companies which economic size varies from 500 to 1000 thousand Euro - in 2010 for one equity euro 0,41 euro of borrowed capital was attributed and in 2014 this indicator decreased even 54 percent, i.e. to 0,19 . 
Agricultural companies, grouping according to types of farming financial risk varies from the smallest (in 2011 2012) for Dairy companies $(0,01)$ up to the biggest (in 2012 - 2014) for farms growing Granivores $(0,42$ - 0,67). Consecutively decreasing financial risk was noticed in agricultural companies who specialize in field crops $(0,39$ $0,13)$.

As expected the average Net Debt to EBITDA Ratios exhibit higher variability over time than the Debt to Equity ratios. This measure is likely a better leading indicator of financial stress. The research have shown that biggest part of Net Debt, attributed to one EBITDA euro was found in agricultural companies which type of farming is Granivores (from 1,59 ( in 2010) to 7,25 (in 2014). The smallest and consecutively decreasing during all the analyzed period Net debt to EBITDA indicators were found in agricultural companies that specialize in field crops $(1,14-0,05)$.

While comparing agricultural companies, grouping according to economic size, it can be stated that the smallest financial stress is found in companies which economic size is up to 500 thousand Euros.

Table -1: Debt indicators of Lithuanian agricultural companies

\begin{tabular}{|c|c|c|c|c|c|c|}
\hline & 2010 & 2011 & 2012 & 2013 & 2014 & $2015 *$ \\
\hline \multicolumn{7}{|l|}{ Debt to Equity Ratio } \\
\hline \multicolumn{7}{|c|}{ Grouping according to types of farming } \\
\hline Fieldcrops & $\mathbf{0 , 3 9}$ & 0,27 & 0,18 & 0,14 & 0,13 & 0,36 \\
\hline Dairy & 0,21 & 0,01 & 0,01 & $\mathbf{0 , 7 8}$ & 0,30 & n.d. \\
\hline Granivores & $\mathbf{0 , 3 6}$ & 0,26 & $\mathbf{0 , 4 2}$ & $\mathbf{0 , 4 8}$ & 0,67 & 0,17 \\
\hline Crops-grazing livestock & $\mathbf{0 , 3 2}$ & 0,25 & 0,27 & 0,18 & 0,12 & 0,16 \\
\hline \multicolumn{7}{|c|}{ Grouping according to economic size, thou Euro } \\
\hline$<500$ & $\mathbf{0 , 3 0}$ & 0,27 & 0,21 & 0,16 & 0,15 & 0,19 \\
\hline $500<1000$ & $\mathbf{0 , 4 1}$ & $\mathbf{0 , 3 8}$ & 0,23 & 0,26 & 0,19 & 0,45 \\
\hline$>=1000$ & $\mathbf{0 , 3 4}$ & 0,21 & 0,29 & 0,20 & 0,22 & 0,15 \\
\hline Average & 0,34 & 0,26 & 0,26 & 0,20 & 0,20 & n.d. \\
\hline \multicolumn{7}{|c|}{ Net Debt / EBITDA } \\
\hline \multicolumn{7}{|c|}{ Grouping according to types of farming } \\
\hline Fieldcrops & 1,14 & 0,50 & 0,22 & 0,04 & 0,05 & n.d. \\
\hline Dairy & 0,34 & $-1,93$ & $-2,08$ & 4,76 & 1,92 & n.d. \\
\hline Granivores & 1,59 & 1,76 & $\mathbf{1 , 8 5}$ & 2,41 & 7,25 & n.d. \\
\hline Crops-grazing livestock & 2,10 & 0,99 & $\mathbf{1 , 5 0}$ & 1,21 & 0,33 & n.d. \\
\hline \multicolumn{7}{|c|}{ Grouping according to economic size, thou Euro } \\
\hline$<500$ & $\mathbf{1 , 1 0}$ & 0,62 & 0,63 & 0,37 & 0,54 & n.d. \\
\hline $500<1000$ & 1,67 & $\mathbf{1 , 8 6}$ & 0,78 & $\mathbf{1 , 6 5}$ & 0,69 & n.d. \\
\hline$>=1000$ & 1,86 & 0,66 & 1,10 & 0,90 & 1,21 & n.d. \\
\hline Average & 1,54 & 0,88 & 0,91 & 1,00 & 0,93 & n.d. \\
\hline \multicolumn{7}{|c|}{ Interest Bearing Loans to Debt } \\
\hline \multicolumn{7}{|c|}{ Grouping according to types of farming } \\
\hline Fieldcrops & 0,44 & $\mathbf{0 , 5 9}$ & 0,47 & 0,32 & 0,34 & 0,33 \\
\hline Dairy & 0,48 & 0,00 & 0,26 & $\mathbf{0 , 6 1}$ & 0,33 & n.d. \\
\hline Granivores & 0,21 & 0,22 & 0,20 & 0,13 & $\mathbf{0 , 4 0}$ & 0,18 \\
\hline Crops-grazing livestock & 0,42 & 0,47 & 0,48 & 0,34 & $\mathbf{0 , 5 6}$ & 0,45 \\
\hline \multicolumn{7}{|c|}{ Grouping according to economic size, thou Euro } \\
\hline$<500$ & 0,54 & $\mathbf{0 , 6 0}$ & 0,48 & 0,40 & 0,45 & 0,26 \\
\hline $500<1000$ & 0,47 & 0,45 & 0,37 & 0,34 & 0,34 & 0,38 \\
\hline$>=1000$ & 0,31 & 0,40 & 0,41 & 0,27 & 0,46 & 0,37 \\
\hline Average & 0,39 & 0,46 & 0,42 & 0,30 & 0,42 & n.d. \\
\hline
\end{tabular}

* In 2015 only 29 Agricultural companies were included into survey 2015. The reason for such sharp drop of them in the survey is that a part of Lithuanian AC had chosen accounting year different from calendar year (July 1st). Therefore, they could not provide farming and other data for year 2015 (FADN survey results 2015).

While analyzing the data provided in Table 2 it can be concluded that Lithuanian agricultural companies have used borrowed capital most efficiently in 2011-2012. After analyzing both Return on Equity ratio and Financial Leverage Effect agricultural companies that specialize in field crops can be emphasized. From one side it can be explained by the fact that in Lithuania plant-growing is a very important agricultural sector and more than 50 percent of agricultural companies act in this sector. From the other side, in 2011-2012 the crop capacity increased and production selling prices were growing.

This explains why Return on Equity increased by 6,3 percentage points (to 18,3 percent) in 2011 and up to 21,4 percent in 2012 in this sector. Efficiency of used of borrowed capital in those years has also increased (from 2,08 to $2,89-2,39$ ). The smallest and even negative Financial Leverage Effect ratio was found in agricultural companies that specialize in dairy.

Table -2: Effect of Financial Leverage of Lithuanian agricultural companies

\begin{tabular}{|c|c|c|c|c|c|c|}
\hline & 2010 & 2011 & 2012 & 2013 & 2014 & 2015* \\
\hline \multicolumn{7}{|c|}{ Return on Equity Ratio (\%) } \\
\hline \multicolumn{7}{|c|}{ Grouping according to types of farming } \\
\hline Fieldcrops & 12,01 & 18,35 & 21,37 & 5,07 & 4,22 & 12,04 \\
\hline Dairy & 5,45 & 0,03 & 2,17 & 2,96 & $\mathbf{7 , 8 7}$ & n.d. \\
\hline Granivores & 9,63 & 3,85 & 11,16 & 8,37 & 0,75 & 5,41 \\
\hline Crops-grazing livestock & 3,43 & 10,54 & 7,43 & 3,33 & 5,41 & 5,87 \\
\hline \multicolumn{7}{|c|}{ Grouping according to economic size, thou Euro } \\
\hline$<500$ & 8,41 & 15,22 & 10,10 & 1,62 & 5,60 & 9,64 \\
\hline $500<1000$ & 9,71 & 8,61 & 15,36 & 4,68 & 4,16 & 14,47 \\
\hline$>=1000$ & 5,18 & 11,10 & 11,62 & 5,01 & 4,53 & 4,96 \\
\hline Average & 6,67 & 11,29 & 12,38 & 4,47 & 4,59 & n.d. \\
\hline \multicolumn{7}{|c|}{ Financial Leverage Effect $(\%)$} \\
\hline \multicolumn{7}{|c|}{ Grouping according to types of farming } \\
\hline Fieldcrops & 2,08 & 2,89 & 2,39 & $-0,07$ & $-0,21$ & 1,87 \\
\hline Dairy & $-0,14$ & - & 0,03 & $-1,29$ & 0,59 & n.d. \\
\hline Granivores & 0,02 & $-0,75$ & 1,34 & 0,27 & $-1,35$ & 0,30 \\
\hline Crops-grazing livestock & $-1,22$ & 1,04 & 0,53 & $-0,21$ & 0,28 & 0,39 \\
\hline \multicolumn{7}{|c|}{ Grouping according to economic size, thou Euro } \\
\hline$<500$ & 0,81 & 2,49 & 0,90 & $-0,57$ & 0,15 & 0,14 \\
\hline $500<1000$ & 0,52 & 0,96 & 1,48 & $-0,22$ & $-0,17$ & 3,82 \\
\hline$>=1000$ & $-0,86$ & 0,79 & 1,69 & $-0,03$ & 0,16 & 0,15 \\
\hline Average & $-0,25$ & 1,24 & 1,40 & $-0,17$ & 0,08 & n.d. \\
\hline
\end{tabular}


The research results show that agricultural companies have used borrowed capital least efficiently in 2013, analyzing companies both by type of farming or by economic sizes. The Financial Leverage Effect indicator was negative.

\section{CONCLUSION}

The analysis of scientific literature has shown that the use of borrowed resources makes it possible to increase the profitability of own capital, but negatively effects to the financial stability of the enterprise. Big debts increase companies' insolvency issues therefore it is very important to correctly choose such capital structure of the company which would minimize capital cost and increase company value.

Most often the scientific literature uses the following indicators in order to evaluate the efficiency of borrowed capital: Debt to Equity Ratio; Debt to Asset Ratio and Return on Equity Ratio. In order to evaluate the financial stress measurement in agricultural companies it is recommended to calculate Net Debt to EBITDA Ratio. A very important indicator of financial risk is Financial Leverage Effect which combines financial leverage and interest coverage risk with tax tariff.

Cereal and milk sectors are very important to the Lithuanian agriculture. The results of research show that Lithuanian agricultural companies that specialize in field crops use borrowed capital most efficiently, meanwhile - companies from dairy sector use borrowed capital least efficiently.

\section{REFERENCES}

[1] Akintoye, I.R. (2009). Sensitivity of Performance to Capital Structure. Banking and Finance Letters. Vol. 1, No. 1, pp. 29-35.

[2] Aleknevičienè, V. (2009). Imonésfinansuvaldymas (Corporate finance management). Kaunas: Spalvųkraitè. $432 \mathrm{p}$.

[3] Al-Shubiri, F. N. (2012). Debt ratio analysis and firm investment: evidence from Jordan. FarisNasif International Journal of Economics and Financial Issues, Vol. 2, Issue 1, pp. 21-26.

[4] Bratka, V., Praulins, A. (2009). Efficiency of borrowed capital in Latvian agricultural holdings. Economics and Management. Vol. 14, pp. 138-144.

[5] Cibulskienè, D., Lileikienè, A., Marcišauskienė, J. (2008).

Kapitalostruktūrossprendimaikaipapsisprendimoprobl emamoderniojefinansavimoteorijoje (Capital structure solutions as a solution to the problem of modern finance theory). Ekonomikairvadyba: aktualijosirperspektyvos. Vol. 4, pp. 72-80.

[6] Collins, S. O., Clement, A. A., Funke, A. R. (2013). Profitability and debt capital decision: a reconsideration of the Pecking Order Model. International Journal of Business and Management, Vol. 8, Issue 13, pp. 24-33.
[7] Damar, H., Farouk, U., Winarto, W. (2016). Analysis of the Effect of Financial Leverage and Liquidity Towards Stock Value and Profitability as the Intervening Variable in Trading Companies Listed at Indonesia Stock Exchange 2010-2014. Jobs. Vol. 1, No. 2.

[8] Dombrovska, S. O., Shostak, I. I. (2016). The role and importance of the enterprises borrowed capital. Economic Processes Management international scientific e-journal. No. 2.

[9] Ellinger, P., Featherstone, A., Boehlje, M. (2016). Leverage of US Farmers: A Deeper Perspective. Choices. Vol. 31, No. 1.

[10] FADN survey results (2010-2015). Ūkiųveiklosrezultatai (ŪADT tyrimoduomenys) 2010-2015. Vilnius: Lietuvosagrarinėsekonomikosinstitutas, 2011-2016.

[11] Fama, E. P. (1980). Agency Problems and the Theory of the Firm. Journal of Political Economy. Vol. 88, pp. 288-307.

[12] Ilie, L., Olaru, R. (2013). Leveraging and Deleveraging: Pluses and Minuses. Procedia Economics and Finance. Vol. 6, pp. 634-644.

[13] Kannadhasan, M., Vinay, G., Parikshit, Ch. (2016). The Role of Financial Performance as a Moderator on the Relationship Between Financial Leverage and Shareholders Return. Journal of Modern Accounting and Auditing. Vol. 12, No.7, pp. 379-387.

[14] Khrawish, A. H., Khraiwesh, A. H. (2010). The determinants of the capital structure: Evidence from the Jordanian Industrial Companies. JKAU: Econ. \& Adm. Vol. 24, No. 1, pp. 173-196.

[15] Kijewska, A. (2016). Determinants of the return on equity ratio (ROE) on the example of companies from metallurgy and mining sector in Poland. Metalurgija. Vol. 55, No. 2, pp. 285-288.

[16] Pettit, J. (2007). Strategic Corporate finance. Applications in Valuation and capital structure. New York: John Wiley, 304 p.

[17] Rajan, R., Zingales, L. (1995). What Do We Know about Capital Structure? Some Evidence from International Data, Journal of Finance. Vol. 50, No. 5, pp. 1421-1460.

[18] Ross, S.A., Westerfield, R.W., Jaffe, J., Jordan, B. D. (2009). Corporate finance: core principles \& applications. McGraw-Hill / Irwin.

[19] Sedlacek, J. (2010). The methods of valuation in agricultural accounting. Agricultural Economics, Czech. Vol. 56, pp. 59-66.

[20] Sumedrea, S. (2015). How the Companies did Structure their Capital to Surpass Crises? Procedia Economics and Finance. Vol. 27, pp. 22-28.

[21] Vătavu, S. (2015). The Impact of Capital Structure on Financial Performance in Romanian Listed Companies. Procedia Economics and Finance. Vol. 32, pp. 1314-1322.

[22] Wu, F., Guan, Z., Myers, R. (2014). Farm capital structure choice: theory and an empirical test. Agricultural Finance Review. Vol. 74, No.1, pp. 115-132. 


\section{BIOGRAPHY}

Lecturer at the Department of Economics, Accounting and

Finance, Faculty of Economics and Management, Aleksandras Stulginskis University, Universitetas str. 10, LT-53361, Akademija, Kaunas distr., Lithuania. E-mail: lina.martirosianiene@asu.lt 